\title{
The Study of Sub-Genre Initiation in Indonesia Lawyers Club Discussion
}

\author{
Malikatul Laila \\ Universitas Muhammadiyah Surakarta \\ Surakarta, Indonesia \\ Mal201@ums.ac.id
}

\begin{abstract}
The article examines the moderator's initiation in Indonesia Lawyers Club (ILC) discussion within the framework of genre analysis. The term sub-genre initiation is one of folded discourses in ILC discussion. The study of the sub-genre initiation is aimed to leverage the audience's response for giving detailed information. The data of utterances are taken purposively based on the richness of information from sessions in ILC discussion during the year 2012 with the selection to 10 available different topics of discussion. The utterances are analyzed by combining the genre analysis paradigm of Swales' about move structure model and the comprehensive pragmatic context. The result shows that the moves as unified structures of functional meaning forming the sub-genre initiation are greeting; recalling past events (by the steps of narrating, establishing opinion, showing emphaty, making analogy, or affirming the fact ect); presenting the topic (by relating the other topics, convincing audience); and addressing the person in concern.
\end{abstract}

Keywords: sub-genre initiation, Indonesia Lawyers Club, moves structure

\section{INTRODUCTION}

Discussion becomes gradually interesting when it keeps to its peak to participants' argument, debate, self expression, and the like since these are conducted for the sake of successful run for the solution of discussion. To have successful discussion, moderator initially presents the aim of the discussion s/he is leading. Among the aims of discussion, are finding solution, explaining problems, confirmatory, and catharsis (Astuti, 2008, pp. 136-137). Typical characteristics of discussion which can be seen as in the Indonesian Lawyers Club (ILC) discussion; however, have stimulated audience to be involved in giving information. The appealing side of ILC discussion is when moderator presents a question in various ways, this can leverage the addressee to give more detailed information. In one side, it is valuable, but on the other, the addressee's response given becomes exceedingly more than the moderator's expectation. The act of moderator's unifiying structure of intention initially in a discussion is quite related to the term 'moves' the moderator will use as sub-genre initiation.

The term 'moves' is closely related in meaning to 'frame'. According to McCarthy, that is meant by 'frame' is referring to either side of the sequence of questions and answers in which it is called move (McCarthy, 1991, p. 13). In conversation, it is also possible to have some moves. One move means one part of the exchange and it is also possible in one move to have many steps. It can be said that move is utterences that are spoken by the speaker/ addresser to the listener/ addressee. Move is defined as the function or role played by a speaker (addresser) in a conversation in its relation to the function or role played by the hearer (addressee) and the commodity being exchanged (Saragih, 2008, p. 14). It means that every clause that is uttered by either addresser or addressee is called move; or, in another word one utterance is one move.

There are many attempts to define genre analysis. Dudley-Evans (1987) claims that genre analysis has its principal aim in pedagogy because it provides a flexible prescription based on analysis that makes suggestions about the layout, ordering, and language appropriateness to a particular writing or speaking task. Moreover, a more simple concept of genre analysis according to Hopkins and Dudley-Evans (1988) refers to an explicit description of the way in which texts are organised. Next, Bhatia (1991) sees genre analysis as an analytical framework which reveals not only the utilizable form-function correlations but also contributes significantly to our understanding of the cognitive structuring of information in specific areas of language use which may help the ESP practitioners to devise appropriate activities potentially significant for the achievement of desired communicative outcomes in specialised academic or occupation areas. In this sense, genre analysis does not have only pedagogical potential but can also illuminate the process of communication in a given genre. Hyland (1992) says that genre analysis is the study of how language is used within a particular context. Genres differ in that each has a different goal and they are structured differently to achieve these goals. Genre analysis thus combines grammatical insights with corresponding socio-cognitive and cultural explanations. It aims at explaining language in use rather than linguistic forms on the surface level (Bhatia 1993).

The study of genre analysis has previously been conducted by many researchers, among others are: Swales (1981, 1990), Amnuai \&Anchalee (2013), Arsyad (2013), Lakic.I (2010), Wiyaka et.al.(2010), Dobakhti (2016), and Songqing Li (2017). According to Swales from his first (1981) and continues to (1990), genre-based analysis was first done by investigating 48 research article (RA) 
introductions from different fields of science and he presented his findings in the work "aspects of Article Introductions", offering a four-move model. Moreover, in 1990, Swales offered a revised model consisting of three moves, urged by some criticisms that it was difficult to differentiate between Move 1 and Move 2. However, it is debatable whether the 3-move model solves this problem.

The study about the initiation sub-genre in ILC discussion has been inspired by Swales' $(1981,1990)$ model of genre analysis on the Research Article (RA) introduction and later by the work of Lakic (2010) about the4-moves model in RA introduction in economics. The different of both and this current study can be seen from written (RA) and the oral (ILC discussion) presentations and from the main purpose starting the communication. In the ILC discussion, the moderator's first greeting to the audience becomes very important because from the moderator's ways of speaking which is powerful, familiar, and responsible, this may impress the audience to get serious stance for further sessions. It is the moderator's speech to be studied. Thus, the releted term may refers to Bakhtin's term as 'speech genre', In his opinion, speech genre is a stable set of types of speech utterances within a sphere of language use. These utterances reflect a compositional structure, style, and thematic content that relate to the speech goal as well as the setting in which the communication takes place (Bakhtin, 1986, p. 60).

Based on the explanation above, to get to know the moderator's continuancy of utterances which reveals his various functional information structures before going on the main session of ILC discussion, the writer's purpose in this article is to present the study of sub-genre initiation in the ILC discussion.

\section{RESEARCH METHOD}

\subsection{The Corpus of the Study}

There are ten topics of ILC discussion the writer took as the corpus of the study: they are about corruption, terrorism, drug abuse, criminality, law injustice, state officials' work ethic, campaign, and problem of common people. The data are utterances in the introduction of the ILC discussion which are termed as sub-genre initiation. From the ten topics as data, taken purposively based on the richness of information during the year 2012, corruption topic becomes the most dominat to occur and it thus represents the dominat structure of moves of ILC discussion. Therefore, people might assume that the moves structure of sub-genre initiation in ILC discussion refers to the typical introduction of the moderator in leading the ILC discussion of law enforcement including corruption.

\subsection{Genre Analysis Method}

For the starting point, analysis of the sub-genre initiation in ILC discussion was based on the model of move structure as outlined by Swales (1990, pp.172-173), especially in the course of identifying utterance as act or move. In Swales's work about the discussion section of research articles (RAs), he proposed eight 'moves' or a segment of text which has a clear communicative purpose set by the writer for the readers; these moves are "(1) background of information, (2) statement of results, (3) (un)expected outcome, (4) reference to previous research, (5) explanation, (6) exemplification, (7) deduction and hypothesis, and (8) recommendation". HSwales suggests the written forms of research articles; however, in this study the writer prefers to apply them to the oral forms or utterances and only on the introduction or sub-genre initiation. Furthermore, this current study is also inspired by the previous study about the move structure of the introduction of RAs which was resulted in 4 move model of introduction in economics; they are establishing the territory, summarising previous research, establishing a niche, and occupying the niche (Lakic, 2010, P. 85). This study which is typically identified as the move structure of sub-genre initiation of ILC discussion has the following moves to propose:

1. Move: Greeting;

2. Move: Recalling the past events

Steps: a) narrating, b) establishing opinion, c) showing emphaty, d) making analogy, and e) affirming the fact;

3. Move: Presenting Topic

Steps: a) relating the other topics and b) convincing audience; and

4. Move: Addressing the man in concern.

Based on Safnil (2000, p. 82) in defining a communicative unit or move, to be the smallest unit of analysis in this study is a clause or a simple sentence because a clause may have only one topic or subject and one comment or predicate. Moreover, the identification of moves in the sub-genre initiation in ILC discussion was done by using linguistic and discourse clues; these are formulaic expression, particular lexical items, cohesive markers (including intonation), by stating opinion or ideas from the moderator's schemata and other kinds of discourse clues, such as facial expressions, body language, and some other non-verbal language used to accompany the moderator's utterances. sub-titles or sub-section titles, paragraph as a unit of ideas, and other possible linguistic and discourse clues available in Indonesian language which might help chunking the text in to moves and identifying the move boundaries.

\section{FINDING AND ANALYSIS}

The sub-genre initiation in the ILC discussion represents the moderator's way to greet participants and to introduce topic for discussion in a more comprehensive and interesting way. The sub-genre initiation ILC discussion functions primarily to socialize the fact of law enforcement in Indonesia which often becomes national problems. Particularly it is to rediscuss current topics published on media which are still perceived uncertaity in society. That's why the solution can be brought to public by inviting participants or men in concern such as mostly lawyers, state officials, victims or criminal experiencers, experts, and tertiary students.

The unified structures of functional meaning to form the sub-genre initiation are greeting audience; recalling the past events (in which this can be done by narrating, 
building opinion, showing emphaty, making analogy, and affirming the fact); presenting the topic sometimes by relating the other topics and convincing the audience about the fact; and addressing the man in concern.

There are two types of move structure in the subgenre initiation as the moderator's variation of introducing to lead the ILC discussion: the first is move structure (A) and the second is (B) below.

\section{(A) Move 1: Greeting;}

\section{Move 2: Recalling the past events}

Steps: a) narrating, b) establishing opinion, c) showing emphaty, d) making analogy,

\section{Move 3: Presenting Topic} and e) affirming the fact;

Step: confirming/ convincing audience; and Move 4: Addressing the man in concern.

(B) Move 1: Greeting;

Move 2: Presenting Topic

Steps: a) giving reason/s, b) relating the other topics, c) narrating/ stating metaphorics/ making analogy, and d) convincing audience; and

Move 3: Addressing the man in concern.

The thing typicalizing the move structure of introduction as sub-genre initiation in ILC discussion lies in the power of moderator to have background knowledge in relation to cases about law enforcement, in which this is revealed in the structure of move 2 (A), about recalling the past events. This is also as the moderator's strategy to lead the audience in keeping interest of the would be topic to state. Because it is not simply presenting the topic of discussion after greeting the audience; instead, the moderator intends the audience to take part seriously within the session by criticizing averything to listen as a form of socialising law enforcement. That's why there will be some steps for recalling the past events, such as: narrating, establishing opinion, showing emphaty, making analogy, or affirming the fact.

On the other hand, the moderator will not immediately recall the past events after greeting the audiense; instead, he directly presents the topic of the would be discussion (the structure of move 2 (B). However, in this move the moderator still keep explaining the reason about the topic being introduced. He had prefered choosing the style of metaphorics or analogy when he explain the topic. Actually, both types of move structure (A) and (B) above show potential authority of moderator about the cases being choosen for topics of discussion. The moderator's knowledge about law enforcement is based on his experiences during which he became a criminal journalist for about 40 years, starting from his career as a reporter in daily news Suara Karya (1972-1978) until he becomes a tvOne director since 2008 (Efendy, 2012).
For further clarity of the analysis of sub-genre initiation, the following explanation of each move may complete ones' understang of the result of analysis.

Move 1: (Greeting) is the moderator's first utterance to greet the audiene of ILC discussion. This functions not only as phatic communion but also to familiarize the situation within the session;

Move 2: (Recalling the past events) refers to the moderator's utterances when he intends to make the audience understand to the related events so that in the next discussion the participants are in the context of the topics. In this move, the moderator conducts it by staging one by one to elaborate the past events. This is done by alternated steps, such as: narrating, establishing opinion, showing emphaty, making analogy, or affirming the fact;

Move 3: (Presenting Topic) is the main purpose of the moderator to get all (participants and audience) keep in track of the topic to discuss. In this move, the moderator will present a bit of some related past events if he will directly present the topic (B); in turn, if he had recalled the past events after greeting (A), the move of presenting topic will be briefly done. So, the main thing he presents the topic is for the sake of confirming/ convincing the audience about whether or not the topic is good or interesting to discuss.

Move 4: (Addressing the man in concern) is the last move of moderator as initiation in ILC discussion because after this act, he will go on the process of addressing a man in concern to give response or ideas. It is the process of seeking for information towards the participants.

Greetings as the first move of sub-genre initiation in ILC discussion have varied in its edition. Beside representing his common typical style of initiation such as: (1) "Pemirsa, kita ketemu lagi di Indonesia Lawyers Club," he has also stressed on the compositional structure based on day time and place coverage, such as: (2) "Pemirsa, selamat malam untuk seluruh pemirsa di seluruh tanah air, kita bertemu kembali di Indonesia Lawyers Club" or "Dimanapun pemirsa berada, diseluruh tanah air ataupun diluar negeri". The moderator has also intended his greeting to appreciate the host who conducted the session of discussion, i.e by mentioning specific location to hold the session, such as (3) "Pemirsa, dimana saja siaran kami bisa ditangkap dan seluruh masyarakat Surabaya dan Jawa Timur yang malam ini menjadi tuan rumah Indonesia Lawyers Club". The moderator' typical greetings in move 1 have been uttered with the accompanying of facial expressions like sharp eyes and hoarse voice in which these implied his responsibility to hold such a routine session 
while discarding of tiresome feelings. His sterned taps to manage the discussion are revealed not only in his typical language but also in his expert in recalling of the past events which might help audience grasp what the would be case to discuss.

Recalling the past events as the second move of sub-genre initiation in ILC discussion can be seen in several steps, such as :

the moderator's narration;

(1) Sungguh banyak peristiwa pada pekan ini. Ada soal Hambalang yang udah dipersoalkan lama tapi tiba-tiba longsor dan rubuh bangunannya. Kemudian ada soal ekstasi, satu setengah juta butir, satu kontaiber. Yang melibatkan aparat terungkap.

his way of establishing opinion;

(2) Dan ini pertama kali jumlah sebesar ini, yang saya tidak mengerti sampai hari ini bagaimana menghabiskan ekstasi satu koma empat juta butir....;

the moderator's showing emphaty;

(3) Baru saja sebuah memori kita putarkan untuk pemirsa dengan meninggalnya anggota senior dari Jakarta Lawyers club pak Bismar Siregar. Ketika beliau meninggal saya mem....menulis di twitter "selamat jalan pak Bismar" yang mulia telah menuliskan leg...sebuah legenda bagi hukum dan keadilan di republik ini, dia adalah pejuang keadilan yang sederhana dan sampai akhir hayatnya, tahun yang lalu, bulan-bulan yang lalu dia masih menyempatkan diri datang ke acara kita ini untuk menyumbangkan pemikiranya.

his making analogy;

(4) Banyak orang yang digigit oleh Nazarudin dari ketua umum partai Demokrat Anas Urbaningrum, Menpora, anggota-anggota banggar DPR kemudian kepala BPN yang memberikan ijin tanah di Hambalang dan banyak lagi yang lain. Awalnya semua yang digigit mengatakan bahwa itu tidak benar, bohong, halusinasi, segala macam. Bahkan ada yang siap di gantung di Monas kalau itu bisa terbukti. Tapi ternyata satu per satu yang digigit oleh Nazarudin itu kok jadi kenyataan.

Presenting Topic as the third move of sub-genre initiation in ILC discussion becomes the main act as initiation of the discussion. The way to attract audience was conducted by the moderator with his indirectness of topic presentation, with such a way of involving on the case, and with such a persuading the participant to be involved in that case. Here are some examples of the act showing the move of presenting topic.
(1) Kami memilih Hambalang karena ini benar-benar mengagetkan, di tengah-tengah isu bahwa uang dari proyek Hambalang mengalir kemana-mana. Menariknya tanah untuk proyek itu sendiri ternyata longsor, tidak layak.

(2) Dan sekarang kita mulai acara mingguan kita yaitu kasus Nazarudin, sampai disini? Itu pertanyaanya. Kenapa? Karena dengan hukuman empat tahun sepuluh bukan masyarakat banyak bertanya, kok hanya segitu hukuman. Begitu hingar bingarnya kasus tersebut.

(3) Tapi yang benar tragedi Tugu Tani. Dibalik tragedi ini yang kami ingin kupas malam ini adalah peredaran narkoba dan minuman keras yang tidak terkendali dan tidak terkontrol. Hanya di Indonesia di 11 sekolah ada minuman keras dijual.

(4) Malam ini kami pilihkan topic yang paling terhangat hari-hari terakhir ini yaitu soal masih tsunami. Tsunami Nazarudin itu sudah kemanamana bahkan memporak porandakan tidak hanya partai Demokrat, tapi membikin gonjang ganjing tanah air.

Addressing the man in concern as the forth move of sub-genre initiation in ILC discussion was chosen by the moderator to the main person in concern, such as: prof. OC Kaligis (Nazaruddin's advocate), Guratno Hartono (Direktur Perataan Bagunan \& Lingkungan Direktorat Jendral Cipta Karya), Teguh (victim from Jepara) in the car accident driven by Aryani, being suspected of extacy, Irjen Pol Saud Usman Nasution (Kadiv Humas Polri), Ansyaad Mbai (Kepala Badan Nasional Penanggulangan Terorisme), and so forth.

Looking at such important persons to have the first chance to give information about the case being discussed, the moderator has always puts the right man in the right place. This means that to be the first to speak up in the forum of ILC may cover the following sphere of debatable arguments. Here the moderator intends the opinion contained within the discussion is worthful as showing the condition of factual problem of law. This kind of strategy to put the addrresee in order is expected to solve the current problems especially dealing with the law enforcement.

\section{CONCLUSION}

The sub-genre initiation of ILC discussion becomes important to study because it can be used as a model of moderator's seek of information towards the participants in a discussion. As a model, this genre presents how the person should behave and have knowledge so that he will be successful to lead the discussion, especially in gathering information which is crucial to share in public.

Although there are two types of move struture in the sub-genre initiation as in (A) and (B) p. 4 above, both 
represent a few distinct exchage only in the superficially move 2 (in which in $\mathrm{A}$ and in B alternate). The main function of the moderator's utterances in alternating the past events and in presenting the topic do not show significant difference; instead, as his strategy to make audience get interest of the topic. Therefore, to be the move structure of sub-genre initiation of ILC discussion will be: greetings, recalling the past events, presenting topic, and addressing the man in concern.

\section{References}

Amnuai, Wirada \& AnchaleemWannaruk. (2013). Investigating move structure of english applied linguistic research article discussions published in international and Thai journals. English Language Teaching: Vol. 6, No. 2, 2013. ISSN 1916-4742, Published by Canadian Centre of Science and Education.

Arsyad, Safnil. (2013). A genre-based analysis on discussion section of research articles in indonesian written by indonesian speakers. International Journal of Linguistics. ISSN 1948-5425. 2013, Vol.5, No. 4.

Astuti, I. S. (2008). Jurnalisme radio: Teori dan praktik. Bandung: Simbiosa Rekatama Media.

Bakhtin, M. M. (1986). The problem of speech genres. In C. Emerson \& M. Holquist (Eds.), Speech genres and other late essays. (pp. 60-102). (V. W. McGee, Trans.). Austin, TX: University of Texas Press.

Bhatia, V. (1991). A genre-based approach to ESP materials. World Englishes 10/2, 153-166.

Bhatia, V. (1993). Analysing genre: Language use in professional settings. London: Longman.

Dobakhti, Leila. (2016). A genre analysis of discussion sections of qualitative research articles in applied linguistics. Theory and Practice Studies. Vol. 6, No. 7, Pp.1383-1389, July 2016, ISSN 1799-2591. DOI: http://dx.doi.org/10.17507.08

Dudley-Evans, A. (1987). Introduction to genre analysis and ESP. ELR Journal 1
Efendy, F. (2012). 40 th jadi wartawan: Karni ilyas lahir untuk berita. Jakarta: Penerbit Buku Kompas.

Hopkins, A. \& T. Dudley-Evans. (1988). A genre-based investigation of the discussions sections in articles and dissertation. English for Specific Purposes 7/2, 113-122.

Hyland, K. (1991). Genre analysis: just another fad?. Forum, 30 (2), 14-17.

Keyser, Wendy, (2014). "Genres of dialogic discussion in high school english: A cross-case study of two courses". Doctoral Dissertations May 2014 current. 102. http://scholarworks.umass.edu/dissertations_2/102

Lakic, Igor. (2010). Analysing genre: Research article introductions in economics. JoLIE 3/2010.

McCarthy, M. (1991). Discourse analysis for language teachers. New York: Cambridge University Press.

Safnil. (2000). "Rhetorical strcuture analysis of the indonesian research articles". Doctoral Dissertation. Australian Nationla University, Australia.

Saragih, A. (2006). Discourse Analysis. Medan: UNIMED.

Songqing Li. (2017). Apology as a crisis response strategy: A genre-based analysis of intercultural corporate apologies. International Journal of Linguistics and Communication, June, 2017, Vol. 5, No. 1 pp. 7383, ISSN: 2372-479X (Print) 2372-4803 (Online), DOI: 10.15640/ijlc.v5n1a8, URL: https://doi.org/10.15640/ijlc.v5n1a8

Swales, J. (1981). Aspects of Article Introductions. Aston ESP Research Report No. 1. Language Studies Unit. University of Aston in Birmingham.

Swales, J. (1990). Genre analysis. English in academic and research settings. Cambridge: Cambridge University Press.

Wiyaka, Sri Wahyuni, and Ajeng Setyorini. (2010). Genre analysis of the english final project abstracts written by the students of english education department of IKIP PGRI Semarang. Kajian Linguistik dan Sastra, Vol. 22, No. 2, Desember 2010: 146-156. 